\title{
Teacher Preparation Process in the United States of America
}

\author{
By Ayşe Elitok Kesici ${ }^{*}$ \& Barlş Çavuş ${ }^{ \pm}$
}

\begin{abstract}
The purpose of this research was to reveal in-class communication practices used in the courses in the teacher preparation programs of the USA depending on classroom observations. Qualitative research method was used in the research. The researcher collected the data through direct participatory and unstructured observation. The researcher made observations in three different classes during the spring semester of 2017-2018 academic year. The study group of the observations was composed of three faculty members and the teacher candidates who were their students. According to research findings, positive faculty member behaviors were; not standing at the same point in the classroom, making eye contact with the students, etc., whereas negative faculty member behaviors were; speaking fast, not calling the students with their names, etc. Positive teacher candidate behaviors were; asking permission to speak by raising up a finger, taking notes in the lesson, etc., whereas negative teacher candidate behaviors were; texting friends during the lesson, sleeping in the lesson, coming to class late, etc. In order to train qualified teachers and make the outcomes of the lessons acquired by teacher candidates, the faculty members should enhance their teaching competencies in accordance with the changing conditions.
\end{abstract}

Keywords: teacher preparation, in-class communication, teacher candidates, learning process

\section{Introduction}

The most important elements of education systems in faculties of education are teacher candidates, faculty members and instructional programs. Among these elements, those that will make a change in behavior in themselves are teacher candidates. The faculty member should take into account the principle of education according to the student while planning, implementing and evaluating the course. The faculty member is supposed to put the activities that will make teacher candidates acquire the outcomes of the education program into practice. Considering the countries developed in education, it can be seen that they manage their human resources very well (Arabac1, 2011). One of the most important factors affecting human resources management is the learning and teaching process. Only if individuals can receive qualified education in this process, they can be brought up as productive, qualified and self-confident individuals that can think multidimensionally (Elitok Kesici \& Çavuş, 2019). The efficiency of the learning and teaching process can be possible through effective communication.

\footnotetext{
*Associate Professor, Department of Curriculum and Instruction, Faculty of Education, Aydın Adnan Menderes University, Turkey.

${ }^{ \pm}$Lecturer, School of Foreign Languages, Aydın Adnan Menderes University, Turkey.
} 
In-class implementations of teacher preparation programs are essential for student success (Visser, Coenders, Terlouw, \& Pieters, 2010). The faculty member should know the objectives of the program very well, effectively get the subject including these objectives acquired to his students, and plan, implement and evaluate the learning and teaching process influentially as the places where the behaviors that education means to achieve are aimed to be achieved at schools are classrooms (Başar, 2016). Besides, the faculty member should keep in mind the readiness levels of teacher candidates. Therefore, they will be able to serve the interests, needs and expectations of the individuals. Furthermore, there is a high relationship between the quality of the faculty member and student success (Opfer $\&$ Pedder, 2011). The need for in-service training for teachers arises as a result of the inability to train qualified teachers. Providing in-service training at work causes various material or moral losses. The fact that teacher candidates are trained qualified can reduce the need for in-service training that they have at the beginning of their duties. By determining the positive and negative behaviors of the faculty members and teacher candidates in in-class communication, the current situation stemming from the communication in the learning and teaching process will be specified and thus, the findings obtained will be a source in coming up with solutions regarding the process.

Success in education depends primarily on the fact that the teacher is trained well (Akpınar, Turan, \& Tekataş, 2004). For this reason, preparing a qualified teacher is essential for the development of the country (Külekçe \& Bulut, 2010). When it comes to teacher preparation, pre-service trainings usually come to mind. Teacher candidates should be provided with the necessary professional skills and such practices as the purpose, principle, method, process, test and assessment, and guidance of the approach they will implement should be taught them well (Güneş, 2016). That is why, there is a general tendency in most countries towards extending the pre-service training period of teachers (Ministere Education Nationale, 2012). Through effective teacher preparation via pre-service and in-service trainings, the cooperation with parents, informing students and the support of school administrations, the negative effects of undesired student behaviors on teachers' classroom management can be reduced. Just as much responsibility falls on teachers in the classroom, the attitudes and behaviors of the students affect the education and instruction environment in the classroom and therefore, the classroom management success of teachers (Can \& Baksi, 2014). In this research, not only the positive and negative behaviors of the faculty members but also the positive and negative behaviors of teacher candidates were determined.

It is expected that teachers are trained well, they constantly update their knowledge and skills, observe their students' learning stages, focus more on useful and logical practices, and use various evaluation techniques (Barnier, 2005). A country's social and economic development and the quality of its education are the issues often associated with the studies conducted. The importance of a teacher preparation system that meets these needs is recognized by many countries when it comes to both sustainable development and qualified education. Teacher preparation programs that will enable teachers to be trained in accordance with the changing education systems should be reviewed (Sözen \& Çabuk, 2013). In this 
study, it was aimed to reveal what the in-class communication practices in the teaching and learning processes were by observing the classes in a leading faculty of education at one of the world's prominent universities. Therefore, the implementations of leading faculties can shed light on the learning and teaching process of less developed faculties.

$21^{\text {st }}$ century competencies can be analyzed in three dimensions as "information", "communication", and "ethics and social impact" (OECD, 2009). In order to be able to raise the individual needed by the society, the faculty members and teacher candidates must have these competencies. So as to be able to overcome in-class communication problems, it is necessary to analyze first what these problems are, provide appropriate learning environments, and make the modern classroom management approach dominant (Sirkeci, 2010). It is also stated that in increasing the performance of higher education, it is necessary for the faculty members at universities to make contributions as well as the students (Kunter \& Baumert, 2006). Considering this requirement, both the faculty members and teacher candidates were observed in this study.

Verbal and non-verbal communication is the most frequently used teaching method by the faculty members when conveying their message to students. For this reason, it is necessary for the communication skills of the faculty members to be well-developed. Only the faculty members with well-developed in-class communication skills can make the meanings common with the teacher candidates. Therefore, they can make the teacher candidates acquire the knowledge, skills and attitude required by the course. Through communication, which is the basis of the formation of a healthy society, individuals can not only understand each other but also produce democratic solutions to their problems without tensions and conflicts (Akbaşl1, 2015; Nartgün, 2014). The fact that verbal and non-verbal communication used in the school and classroom environment is effective and healthy enables students to improve their skills regarding autonomous thinking and expression. Effective communication also enables creativity, the emergence of different thoughts, and the acquisition of rich experiences in individuals' relationships with each other (Tomul, 2016). Having undergraduate education within an effective communication environment will positively influence teacher candidates to be a good teacher. Thus, teacher candidates will be able to use positive communication skills in their classrooms when they start their careers as teachers.

It is thought that in-depth analysis of the positive and negative behaviors exhibited will be rewarding in improving all kinds of communication environments at the university level and providing a more effective learning and teaching environment, and in filling the gap in the literature.

\section{Purpose}

The purpose of this research was to reveal in-class communication practices used in the courses in the teacher preparation programs of the United States of America depending on classroom observations. 


\section{Methodology}

\section{Research Design}

In this study, qualitative research design was used with the aim of being able to understand the learning and teaching process experiences of the faculty members and teacher candidates and examine their in-class practices in depth and in a detailed manner (Creswell, 2009; Patton, 2002; Y1ldırım, 1999), and the research question was analyzed without using standardized tools (Johnson \& Christensen, 2012). Qualitative methods are based on text data and imaginary data, and they have unique steps and different patterns in data analysis (Creswell, 2016). Case study pattern was used in order to understand the behaviors of the faculty members and teacher candidates in the learning and teaching process. Case study, which is one of qualitative research models, is considered a distinguishing approach used to seek answers for scientific questions (Büyüköztürk et al., 2018). Case studies aim to make deeper descriptions, create patterns and make comments with logical inferences on a thematic basis (Paker, 2015). It is a research method that is used to understand, define and describe the reasons, causes and consequences of current cases when there is no control of the researcher on the variables (Yin, 2014). In case study, it is possible to describe and examine a research topic whose boundaries are pre-determined, in a detailed manner and in its actual environment (Birinci, Kılıçer, Ünlüer, \& Kabakçı, 2009). The case to be chosen as a research topic can be a class, school and community. The case may also be a process involving the implementation steps such as an undergraduate instructional program (Creswell, 2012). Therefore, in this research design, it was aimed to analyze the case in its own environment, in its own flow in detail and describe it thoroughly. In this regard, observational case study approach was used in the research (Büyüköztürk et al., 2018). There was no intervention of the researcher in the process, environment and the event. Considering the complexity and diversity of educational environments and educational objectives, case studies conducted with different purposes are deemed valuable data sources for researchers (Ozan Leylum, Odabaşı, \& Kabakçı Yurdakul, 2017). Case study is a method in which a case is examined in depth (Shuttleworth, 2008). The main data collection tools for case study are interview and observation techniques (Zainal, 2007). In this study, the data was collected through observation technique.

\section{Data Collection}

The data was collected through direct participatory and unstructured observation. Unstructured observation is a type of observation that gives the observer freedom to collect and record information without structuring before the observation. These can be in the form of taking notes and keeping a diary. It requires the observer to undertake the tasks of synthesizing, abstracting and organizing information. In participatory observation approach, the observer makes observations without any external influence (Büyüköztürk et al., 2018). In this research, the observations were made by the researcher in three different classes in 
a faculty of education in the United States of America during the spring semester of 2017-2018 academic year. The researcher sat on an armrest chair on the back row in the classroom and tried to take notes of everything without influencing any of the things happening in the classroom. At the end of each observation, the observation records were reviewed by the researcher and they were completed if there was any lacking information. Moreover, the observations made on that day were transcribed into word program on the computer on the same day. The reason for this day-to-day computer transcription is the effort to minimize data loss. In transcribing the data day by day, the researcher can remember a situation (s)he observed during the observations and write it more detailed, which, in turn, prevents data loss.

The observations were carried out for 2 months in three different $4^{\text {th }}$ grades of the faculty of education at a university in the United States of America. The observations started on 05 February 2018 and ended on 12 April 2018. Each lecture lasted for 1 hour and 15 minutes. Every week, a total of 7.5 hours of inclass observations were made. In total, the researcher made 60 hours of observation, 30 hours per month, in 3 different classes. The classes observed were; psychological counseling and guidance teaching class, primary school teaching class, and social studies teaching class. 17 lectures were observed in social studies teaching class and primary school teaching class, while 14 lectures were observed in psychological counseling and guidance teaching class. The observations in social studies and primary school teaching classes lasted 8.5 weeks, whereas in in psychological counseling and guidance teaching class, the observations lasted 7 weeks. In this class, the observation period was shorter because the teacher held exams from time to time. A total of 115 pages of data were collected from the observations in 3 classes. At the time of the observations, each situation was recorded and then, the data was aimed to be determined by content analysis. For the data obtained from the observations, content analysis and descriptive statistics were used together. Content analysis is a scientific approach that allows verbal, written and other materials to be examined objectively and systematically (Tavşancil \& Aslan, 2001). Content analysis requires an in-depth analysis of the data collected and allows to reveal the previously unclear themes and dimensions (Can \& Baksi, 2014). Through content analysis, the beliefs, attitudes, values and thoughts of people or groups can be revealed (Stemler, 2000).

\section{Data Analysis}

Descriptive survey, which is one of the qualitative research methods, was used in the research. Data texts were read several times and then coding was formed after making evaluations via line-by-line reading technique. The concepts used while creating the codes were formed by taking the data obtained from the observations, the purpose of the research and related literature into consideration. After the coding process, the codes created were combined together and their common points were determined. Therefore, the themes forming the outlines of the research findings were identified and content analysis was performed. After the 
content analysis, descriptive analyses were performed on these texts and the data was presented to the reader.

\section{Study Group}

The study group of the study was formed by purposeful sampling method. Purposeful sampling method is useful for exploring and explaining the phenomena and events as it examines a situation in depth (Merriam, 2013; Yıldırım \& Şimşek, 2018). The researcher forms purposeful sampling in order to make an in-depth examination of the research, select the situations containing rich information for the depth of the research and learn quite a lot of things about the issues of central importance in accordance with the purpose of the research (Patton, 2017).

The first of the classes in which the observations were made was social studies teaching, while the second was psychological counseling and guidance teaching, and the third was primary school teaching. The observations were made at the $4^{\text {th }}$ grades of these three classes. The group observed was the 3 faculty members and the students in the classes of these faculty members. The faculty member of social studies teaching class was an assistant professor. The faculty members of the other two classes were teaching assistants, both of whom continued their doctoral education.

\section{Validity and Reliability}

Validity is namely the fact that the findings obtained from the research are actually related to what they appear to be or not. Reliability is the fact that the measurement made is consistent or stable (Robson, 2015). Karasar (2018) defined validity and reliability as "Validity is the degree to which the thing to be measured has been measured. Reliability is the stability between the independent measurements of the same thing". Presenting the findings obtained from the observations made directly increased the reliability and validity of the research.

Furthermore, in order for the data obtained to be better understood, the data were presented in tables where necessary. In this respect, the study is a descriptive research due to the fact that it aims to reveal the present situation as it is.

The observations lasted eight weeks. The researcher kept the duration of the observations long. The reason for this was to try to ensure that students and the teacher considered the researcher as if she were a member of the class. This precaution is necessary so as to be able to capture the natural atmosphere of the class and minimize artificial behaviors, which, in turn, positively affects the validity and reliability of the research. Teachers agreed to make observations in their classrooms. Therefore, the research attached importance to the principle of volunteering.

\section{The Characteristics of the Classes Observed}

There are a total of 12 teacher candidates in the Social Studies Teaching class. 11 of them are female and 1 of them is male. All the students in this class are 
white. The class is quite spacious. The floors are covered with carpets. The chairs and tables are ergonomic. These chairs and tables are foldable and they can be dragged. They have wheels under them. 3 walls of the class are covered with white boards. The other wall is thoroughly covered with maps. These maps are World Map and the Map of the USA. There is also a material room in this class. The classroom has a projector, a computer and an opaque projector.

From time to time, the teacher goes into the material room and brings the necessary materials for the lecture. The students sit around the tables in groups of 6, 4 and 2 persons. The students have always sat in the same place for 8 weeks. The seating arrangement is as 3 groups around 3 tables. The faculty member of this class was a 40 -year-old female assistant professor.

There are 21 teacher candidates in the Primary School Teaching class. 20 of them are female and 1 of them is male. All students in this class are white. The class is a medium-size class. The floors are covered with ceramics. The class has armrest chairs. Each student sits individually. Only one wall of the class has a regular-size whiteboard. The classroom has a projector, a computer and an opaque projector. The paint of the class is not in a very good condition and it can be seen that some of the paint is worn-out. The class sits in a u-layout all the time. The faculty member of this class was a 35-year-old female instructor who continued her $\mathrm{PhD}$ education.

There are 21 teacher candidates in the Psychological Counseling and Guidance Teaching class. 15 of them are female and 6 of them are male. There is an AfroAmerican schoolgirl in this class. There are armrest chairs more than necessary in this class. Some of them are stacked on the bottom of the walls, while some others are in the middle of the class and empty. They create a chaotic environment in the class. Other characteristics of this class are the same as the primary school teaching class. The classroom has a projector, a computer and an opaque projector. The paint of the class is not in a very good condition and it can be seen that some of the paint is worn-out. The class sits in a u-layout all the time. The faculty member of this class was a 38-year-old female instructor who continued her $\mathrm{PhD}$ education.

\section{Results}

In this section, the findings regarding the purpose of this research, which was to reveal in-class communication practices used in the courses in the teacher preparation programs of the United States of America depending on classroom observations, were given. The themes and categories obtained as a result of the analysis of the research data is given in Table 1 .

Table 1. The Themes and Categories regarding the Characteristics of in-class Communication

\begin{tabular}{|l|c|}
\hline Themes & Categories \\
\hline \multirow{2}{*}{ Faculty Member Behaviors } & Positive Faculty Member Behaviors \\
\cline { 2 - 2 } Teacher Candidate Behaviors & Negative Faculty Member Behaviors \\
\cline { 2 - 2 } & Positive Teacher Candidate Behaviors \\
\hline
\end{tabular}


In Table 1, the characteristics of in-class communication were gathered under two themes in accordance with the findings obtained as a result of the observations. These themes were; faculty member behaviors and teacher candidate behaviors. Under each theme, the findings regarding the positive and negative sides of each theme were presented as categories.

\section{Faculty Member Behaviors}

Positive Faculty Member Behaviors. Teaching in the middle of the class by getting closer to the students and sometimes getting away from them, letting the student who wants to speak by raising hand, having a sufficient, impressive and lively tone of voice, dividing the students into groups of four, smiling to the class, teaching with laughter and answering the students cheerfully, giving examples from childhood and family, making eye contact with all of the students, awakening the classroom speaking very silently by shouting, saying hello to the class with a strong tone of voice by repeating what the students say, bringing pens and chocolate candies to the students as Valentine's Day gifts and letting the students who would like to take them, using body language effectively by doing as if she is holding something in her hands, confirming what the students say, answering the students' questions, giving an example of anger with strange sounds and mimics, giving homework to students, pretending to sing in the lesson, instructing the students during the lesson, asking questions to the class by stopping the video and making explanations, teaching by snapping her fingers, guiding the students that they can also go out of the class during the lesson for group work, making the students join the lesson by asking them questions, going next to the students working outside the class, teaching by stretching words and lowering or raising her voice, teaching the subject by constantly waving his hands, saying "Federaliiiiiissmmm" by lowering and raising her voice and stretching the word a little, speaking as if telling a story by lowering her voice, using her body language effectively and teaching as if showing off, going next to the groups and listening to them while group studies are going on, drawing attention to the important points of the lesson, telling the important source about the lesson, turning on music in the lesson, always coming into the class five minutes before the lesson, wandering in the classroom occasionally, using her hands, gestures and facial expressions, using her tone of voice effectively, calling the students by their names, using a name tag and making each student use one at the beginning of the year, taking notes while teacher candidates are making presentations and contributing to the presentations verbally, teaching the lesson by making jokes, giving examples about the subject, saying "welcome to the lesson", asking how the students have spent their weekends, thanking the students, visiting all the groups during the group works, apologizing to the students, listening to the student presentations, teaching by imitating her parents, making good wishes, reminding the weekend activity, making additional explanations following what the students say, writing the agenda on the board, answering those who have questions, making the students take notes in the lesson, collecting and evaluating these notes after each lesson, bringing these notes into the next lesson and giving them to the students, turning 
down half of the light during the presentations, apologizing for being just a few minutes late, giving advices to the students for their studies, giving feedback to the students, giving advices to the students for their final reports and giving examples, giving examples from her mother's class, telling the students the topic of next week at the end of the lesson, saying hello and entering the classroom with joy, speaking by snapping her fingers, asking the groups to talk to each other about how they have spent their holidays, tell a memory with her mother, asking the students to shut down their computers while a teacher candidate is making a presentation, asking the students to read a script she has given, give examples from herself, her husband and friends, making funny additions by lowering and raising her tone of voice, finishing the lesson by reflecting the subject of next week on the wall, asking the students how they are, shouting 8 times as "children cannot be sold" by hitting the table by hand, teaching the lesson in the garden by using the drama method (the teacher was wearing a t-shirt writing "teachers cannot be wimps"), making explanations before the acts begin.

Negative Faculty Member Behaviors. Teaching the lesson in front of the board, sitting on the chair in the lesson and dealing with the documents, teaching the lesson by reading from the article, teaching mostly by looking at only a student, teaching the lesson with hands in her pockets, teaching sometimes by sitting on the chair, stretching her body, moving her shoulders and head from left to right, leaving her mouth open for a long time and then, shirring her lips like a child, describing by rubbing her feet on the floor, sometimes teaching with the same tone of voice, drinking cola, tea and water in the classroom, spending the lesson time with the same students, using sounds like "uff, yaa, thh", not turning on the lights even though the classroom is dark, looking at the photos of the students in the computer so as to remember the names of the students, speaking fast, shaking her head strangely, teaching by opening her eyes more than usual, showing more interest to a specific student (such as the favorite of the teacher), giving candies to the students but not having enough candies for all the students, asking the students to turn on the light after the lesson is over (to take a photo) though it is dark all the lesson, looking at her phone, never guiding the students in group work, teaching by looking at the same group of students (this group is always more interested in the lesson), making weird movements, confusing the 4 year old and the $4^{\text {th }}$ grade in the drama script during the lesson.

\section{Teacher Candidate Behaviors}

Positive Teacher Candidate Behaviors. Asking to speak as a student by raising a finger, introducing a book in the classroom, smiling sincerely to the teacher, speaking without looking at the presentation, using hands effectively, waiting quietly until the teacher comes, taking notes as students, taking a photo of what is written on the board, thanking the class after the presentation finishes, teaching the lesson by heart, listening to the lecture, wearing a special necklace for the presentation, participating more actively as a specific group in the class, asking the teacher to speak, introducing an activity about a person with leukemia by a 
female student and making volunteer students fill in a form and giving a separate paper to those who want to make a donation.

Negative Teacher Candidate Behaviors. Teaching the lesson in front of the board and not making much eye contact with the class while making the presentation, only walking from left to right in front of the board in a straight line, yawning in the lesson, eat something in class during the lesson, texting friends on the Internet or on the phone, not being willing to participate in the group work, always giving examples in the class by the same female student, never speaking and sharing her views as a female student in group work, surfing on Facebook account, looking at the fashion pages on the Internet, talking among themselves off the lesson, always joining the lesson by the same students, sitting in the same place every lesson, coming to class late, chewing gum, sitting by leaning back on the chair in the classroom, wasting time in the lesson, leaving the class while the lesson is going on and then coming back later in the class, not listening to the lesson, making a loud noise in the class, sleeping as students in the lesson, teaching by reading from the presentation on the wall, yawning before the presentation, being interested in the lesson by as much as two students, presenting by reading from the computer, speaking fast, with a low and the same tone of voice while making the presentation, writing of a student that next week is the death week (I guess the student writes this because of being given a lot of homework for next week), leaving the class by a student without saying anything to the teacher.

\section{Discussion}

In the research, it was found that the faculty members exhibited such positive behaviors as using their verbal and non-verbal communication skills very well, being cheerful in the classroom, guiding all the groups during group work, calling the students with their names, thanking to the students, apologizing to them when necessary, etc. Communication is an interaction process among individuals, clusters and societies that enables the mutual transmission of thoughts, wishes and emotions through such symbols as words, texts, images and hand gestures. In the light of the findings obtained from the research, it could be said that faculty members could provide this interaction in their communication skills. The century that we are in requires not only communication but also quality and effective communication (Kaya, Sungurtekin, \& Deniz, 2017). For this reason, the fact that the faculty members exhibit these positive communication skills may serve to develop positive characteristics in teacher candidates who are the teachers of the future. It was also determined that student participation, group interaction, teacher guidance, student evaluations, teaching evaluation and feedback, which were present in the measurement tools, were aiming to determine the teaching competencies (Doğanay \& Yeşilpınar Uyar, 2020). Some of these features were also found in the in-class observations made. 
Contemporary teaching directs students to thinking and questioning (Kozanitis, 2005). Faculty members fulfill these duties by making teacher candidates effective and directing them. Communicating effectively requires taking appropriate tools, the use of a correct language and all other aspects within the context into consideration (OECD, 2009). The fact that verbal and non-verbal communication skills of the faculty members were developed could be interpreted as that they could establish effective communication skills in terms of language. It was revealed that in addition to the personal characteristics of the faculty members, the way they behave to their students was also important in the teaching process (Boysen, Richmond, \& Gurung, 2015). The ways of behavior can also have influence on individuals' self-efficacy and their academic achievement.

It was also revealed in the research that the faculty members exhibited some negative behaviors such as speaking fast and with the same tone of voice, their hands in their pockets, in a dark classroom and always by making eye contact with the same students, etc. Avoiding talking too fast in communication leaves a good impression; nobody wants to listen to someone speaking really fast (Özdemir, 2020). In another study, it was concluded that more than half of the faculty members were not at an adequate level in terms of their "communication" skills. The professional qualifications that should be present in the faculty members are noted to be such qualifications as communicating effectively, managing the classroom very well, using time effectively, evaluating the learning and guiding (Aydın, 2015). In order for teachers to establish a positive relationship with other individuals and especially students, they should be able to perceive themselves and see the reactions of students together with their own behaviors (Çalışkan \& Yeşil, 2005). In other words, the faculty members should be able to analyze the effects of these behaviors on teacher candidates by realizing the positive and negative behaviors they exhibit. As a result of analyzing the data obtained in a descriptive research conducted with the participation of 458 students, it was concluded that the faculty members had effective communication skills which were to be improved, though. Besides, a positive and significant relationship was found between the communication skills of the faculty members and their instructional skills (Y1lmaz, Yoncalı \& Çimen, 2010). In another research, it was pointed out that the faculty members had deficiencies in listening, diction, using gestures and mimics (Bayram, Göker, Sarıkaya, \& Kumandaş Öztürk, 2018).

In the research, it was also found that the teacher candidates exhibited such positive behaviors as asking to speak by raising their fingers, joining the lesson effectively, using non-verbal communication effectively, waiting quietly until the teacher comes, taking notes in the lesson and listening to the lesson; whereas they exhibited such negative behaviors as speaking quietly and with the same tone of voice, always teaching in the front of the board, not having too much eye contact with the class, texting friends on the Internet or on the phone, etc. In the light of the findings obtained, it could be said that although the teacher candidates had positive behaviors, it was necessary to improve these behaviors. In order to increase the frequency of positive behaviors, classroom settings should be arranged in accordance with the interests, needs and expectations of teacher candidates. Instructional processes should stimulate and support thinking (Boysen, Richmond, 
\& Gurung, 2015), and it is a necessity to improve the faculty members accordingly. In another research carried out, it was determined that there were negative observations regarding speech fluency, tone of voice, using clear expressions, emphasis, and diction sub-dimensions of verbal communication in terms of teacher candidates (Ay, 2015). The teacher should be aware of the behaviors that involve negative but not intentional and malicious attitudes, and those that are damaging and repetitive. It is necessary to carefully monitor the real intention and postbehavioral expectation of the student exhibiting an undesired behavior that may be associated with this behavior (Sarıtaş, 2006). In order to provide adequate teaching, student participation, group interaction, teacher guidance, student evaluations, teaching evaluation and feedback are required (Catano \& Harvey, 2011). These skills should also be developed in teacher candidates.

It was also revealed in the research that negative teacher candidate behaviors were quantitatively higher than positive teacher candidate behaviors. New attitudes and behaviors are produced at school as well as the attitudes and behaviors determined by the communication environment within the school. This production also requires that the communication between the teacher and the student is healthy (Bayram, Göker, Sarıkaya, \& Kumandaş Öztürk, 2018).

In the light of the findings obtained, it could be also said that the quality of the communication within the classroom affects both teacher candidates and faculty members. The communication and interaction order performed within the classroom environment requires being able to look at the class as a whole group. It is an obligation to establish effective communication between the faculty member and the student in the learning and teaching process. Effective teachers are also those who establish effective communication (Bayram, Göker, Sarıkaya, \& Kumandaş Öztürk, 2018). In a research conducted with teachers, it was revealed that the teachers thought the education they received in their undergraduate education was insufficient for improving their in-class communication skills (Can $\&$ Baksi, 2014). For this reason, the communication skills of the faculty members working in the faculties of education are of great importance in determining the quality of the education provided (Bayram, Göker, Sarkkaya, \& Kumandaş Öztürk, 2018). Being able to look at the class as a whole group will enable the individuals in the group to see that they are there for a common purpose. In this case, it can serve to attain positive acquisitions in cooperation and coordination. The teachers stated that the positive attitudes and behaviors of the students had positive effects on the teachers' classroom management success. The teachers also emphasized that the negative behaviors exhibited by the students within the classroom caused the teachers to exhibit negative attitudes towards the class (Can \& Baksi, 2014).

\section{Conclusions and Suggestions}

As a result of the findings obtained from the research, positive faculty member behaviors were; saying "welcome" to the students at the beginning of the lesson, teaching by walking around in the classroom, enabling the students to actively participate in the lesson, using their verbal and non-verbal communication 
skills very well, being cheerful in the classroom, giving examples from their own lives, using eye contact effectively in the classroom, assigning homework to the students and making them take notes, guiding the students whenever needed, guiding all the groups during group work, coming into the classroom 5 minutes before the lesson, using music in the lesson, calling the students with their names, using their tone of voice effectively, using name tags at the beginning of the year, thanking to the students, apologizing to them when necessary, giving feedback and suggestions to the students.

The results obtained regarding negative faculty member behaviors were; teaching by standing or sitting in a fixed place in the classroom, by speaking fast and with the same tone of voice, their hands in their pockets, in a dark classroom and always by making eye contact with the same students, drinking cola, tea and water in the classroom. Based on the findings obtained from the research, it is deemed necessary to improve the verbal and non-verbal communication skills of the faculty members. In the present study, it was found that the number of positive behaviors exhibited by the teaching staff was higher than the negative ones. This finding can be considered a positive conclusion. On the other hand, it is an undeniable fact that the negative effects of the negative behaviors observed will also be negative, and thus, there is a need to transform these negative behaviors into positive ones.

As a result of the research, positive teacher candidate behaviors were; asking to speak by raising their fingers, joining the lesson effectively, using non-verbal communication effectively, waiting quietly until the teacher comes, taking notes in the lesson and listening to the lesson, whereas negative teacher candidate behaviors were; speaking fast while making the presentation, speaking quietly and with the same tone of voice, always teaching in the front of the board, not having too much eye contact with the class, yawning in the lesson, eating something in class during the lesson, texting friends on the Internet or on the phone, surfing on Facebook account, talking among themselves off the lesson, always joining the lesson by the same students, sitting in the same place every lesson, coming to class late, chewing gum, sitting by leaning back on the chair in the classroom, wasting time in the lesson, leaving the class while the lesson is going on, not listening to the lesson, making a loud noise in the class, and sleeping in the lesson.

It was remarkable to reveal as a result of the research that negative teacher candidate behaviors were quantitatively higher than positive teacher candidate behaviors. Therefore, necessary measures should be taken so as to produce positive new behaviors within the classroom.

Based on the research, it could be seen that the number of positive faculty member behaviors was higher than the number of positive teacher candidate behaviors, whereas the number of negative teacher candidate behaviors was higher than the number of negative faculty member behaviors. Therefore, it can be said that there is a necessary to decrease the number of negative teacher candidate behaviors. Further qualitative and quantitative research can also be carried out analyzing the behaviors of faculty members and teacher candidates at each grade level. 
It can also be said that the quality of the communication within the classroom affects both teacher candidates and faculty members. Therefore, it is a necessity to improve the quality of classroom environments. For this reason, trainings can be provided for the faculty members focusing on how they can improve their communication skills and how they can make teacher candidates acquire these skills. In this regard, it is required that the courses involving classroom management skills should be applied courses. Furthermore, the dimensions like teaching competencies, effective presentation, student-centered teaching, and effective communication should also be taken into consideration in the programs preparing faculty members and teacher candidates.

\section{References}

Akbaşl1, S. (2015). In-Class Communication and Interaction. In S. Ruhi (ed.), Classroom Management. Ankara: Anı Publishing.

Akpınar, B., Turan, M., \& Tekataş, H. (2004). The Competencies of Teacher Candidates from the Perspectives of Teacher Candidates. In $13^{\text {th }}$ National Educational Sciences Congress, İnönü University, Faculty of Education. Malatya, Turkey.

Arabacı, İ. B. (2011). Education Expenditures in Turkey and OECD Countries. Electronic Journal of Social Sciences, 10(35), 100-112.

Ay, S. T. (2015). Educators in terms of Effective Communication Skills. The Journal of Academic Social Science Studies, 41, 367-381.

Aydın A. (2015). Classroom Management. Ankara: Pegem Publishing.

Barnier, G. (2005). Théories de l'apprentissage et Pratiques d'enseignement. (Learning Theories and Teaching Practices). Retrieved from: http://www.formations.philippec lauzard.com/Theories_apprentissage.pdf. [Accessed 17 April 2020].

Başar, H. (2016). Classroom Management. 20 ${ }^{\text {th }}$ Edition. Ankara: Anı Publishing.

Bayram, A., Göker, S. D., Sarıkaya, H. S., \& Kumandaş Öztürk, H. (2018). A Study on Classroom Communication Skills of Instructors Lecturing in Undergraduate, Graduate and Postgraduate Programs at the Faculties of Education. Abant Izzet Baysal University, Journal of Education Faculty, 18(1), 77-94.

Birinci, G., Kılıçer K., Ünlüer, S., \& Kabakçı, I. (2009). A Methodological Evaluation of Case Study Researches in the Field of Educational Technology. In $3^{\text {rd }}$ International Computer and Instruction Technologies Symposium. Karadeniz Technical University, Trabzon, Turkey.

Boysen, G. A., Richmond, A. S., \& Gurung, R. A. (2015). Model Teaching Criteria for Psychology: Initial Documentation of Teachers' Self-Reported Competency. Scholarship of Teaching and Learning in Psychology, 1(1), 48.

Büyüköztürk, Ş., Çakmak, E., Akgün, Ö. E., Karadeniz, Ş., \& Demirel, F. (2018). Scientific Research Methods. Ankara: Pegem Academy Publishing.

Çalışkan, N., \& Yeşil, R. (2005). The Teacher's Body Language in Educational Process. Gazi University, Journal of Kırşehir Education Faculty, 6(1), 199-207.

Can, E., \& Baksi, O. (2014). The Effect of the Attitudes and Behaviors of Students in Classroom to Teachers' Classroom Management Success. Asian Journal of Instruction, 2(1), 86-101.

Catano, V. M., \& Harvey, S. (2011). Student Perception of Teaching Effectiveness: Development and Validation of the Evaluation of Teaching Competencies Scale (ETCS). Assessment \& Evaluation in Higher Education, 36(6), 701-717. 
Creswell, J. W. (2009). Research Design: Qualitative, Quantitative, and Mixed Methods Approaches. California: SAGE Publications.

Creswell, J. W. (2012). Educational Research: Planning, Conducting, and Evaluating Quantitative Research. $4^{\text {th }}$ Edition. Boston: Pearson Education Inc.

Creswell, J. W. (2016). Qualitative Research Methodologies: Qualitative Research and Research Design according to Five Approaches. Translated by S. B. Demir, \& M. Bütün. Ankara: Siyasal Bookstore Publishing.

Doğanay, A., Yeşilpınar Uyar, M. (2020). Öğretim Elemanlarının Öğretim Yeterlikleri Algisı Ölçeği (ÖYAÖ) (Perception of Faculty Members' Teaching Competencies Scale (PTCS): Validity and Reliability Study). Uşak Üniversitesi Eğitim Araşttrmaları Dergisi, 6(3), 68-89.

Elitok Kesici, A., \& Çavuş, B. (2019). The Evaluation of Teacher Training Programs in the United States of America in terms of Student-Centered Practices Used in Class. Journal of Education and Training Studies, 7(10), 78-89.

Günes, F. (2016). Approaches and Models in Teacher Education. Journal of Kırşehir Education Faculty, 17(3), 413-435.

Johnson, R. B., \& Christensen, L. B. (2012). Educational Research Methods: Quantitative, Qualitative, and Mixed Approaches. $4^{\text {th }}$ Edition. Los Angeles: SAGE Publications.

Karasar, N. (2018). Scientific Research Methods. Ankara: Nobel Academic Publishing.

Kaya, M. F., Sungurtekin, D., \& Deniz, S. (2017). Üniversitelerde Öğretim Elemanı Kaynaklı Iletişim Sorunları. (The Communication Problems Derive from Academicians at the Universities). Trakya Üniversitesi Eğitim Fakültesi Dergisi, 7(1), 176-195.

Kozanitis A. (2005). Les Principaux Courants Théoriques de l'enseignement et de l'apprentissage: Un Point de Vue Historique. (The Main Theoretical Currents of Teaching and Learning: A Historical Perspective). Montréal: École Polytechnique.

Kunter, M., \& Baumert, J. (2006). Who is the Expert? Construct and Criteria Validity of Student and Teacher Ratings of Instruction. Learning Environments Research, 9(3), 231-251.

Külekçe, E., \& Bulut, L. (2010). The Comparison of the Teacher Training Systems in Turkey and the USA. In International Conference on New Trends in Education and Their Implications (pp. 205-215). Antalya, Turkey.

Merriam, S. B. (2013). Nitel Araştırma: Desen ve Uygulama İçin Bir Rehber. (Qualitative Research: A Guide for Design and Practice). Edited by S. Turan. Ankara: Nobel Yayınevi.

Ministere Education Nationale (2012). Formation des Enseignants: Éléments de Comparaison Internationale, Concertation sur la Refondation de l'école de la République. (Teacher Training: Elements of International Comparison, Consultation on the Refoundation of the School of the Republic). France: Ministere Education Nationale.

Nartgün, Ş. (2014). Communication in Class. In T. Argon, \& Ş. Nartgün (eds.), Classroom Management. Ankara: Maya Academy.

OECD (2009). $21^{\text {st }}$ Century Skills and Competences for New Millennium Learners in OECD Countries. OECD Education Working Papers, No. 41. OECD Publishing.

Opfer, V. D., \& Pedder, D. (2011). The Lost Promise of Teacher Professional Development in England. European Journal of Teacher Education, 34(1), 3-24.

Ozan Leylum, Ş., Odabaşı, H. F., \& Kabakçı Yurdakul, I. (2017). The Importance of Case Study Research in Educational Settings. Journal of Qualitative Research in Education, 5(3), 369-385.

Özdemir, A. (2020). Beden Dili, Etkili Iletişim, Etkili Konuşma. (Body Language, Effective Communication, Effective Speaking). Ankara: Gece Kitaplığı. 
Paker, T. (2015). Case Study. In F. N. Seggie, \& Y. Bayyurt (eds.), Qualitative Research: Methods, Techniques, Analyses and Approaches (pp.119-134). Ankara: Anı Publishing.

Patton, M. Q. (2002). Qualitative Research \& Evaluation Methods. California: SAGE Publications.

Patton, M. Q. (2017). Qualitative Evaluation and Research Methods. Thousand Oaks, CA: SAGE Publishing.

Robson, C. (2015). Scientific Research Methods: Actual World Research. Ankara: Anı Publishing.

Sarıtaş, M. (2006). Strategies Used in order to Change and Correct Unwanted Student Behaviors in the Classroom according to Teacher Candidates' Evaluations. Uludağ University, Journal of Education Faculty, 19(1), 167-187.

Shuttleworth, M. (2008). Case Study Research Design. Retrieved from: https://explorable. com/case-study-research-design. [Accessed 06 April 2020].

Sirkeci, B. (2010). Discipline Problems Encountered during Class Management by the Teachers Working in the First Level of the Private and Public Schools and their Approaches in Handling the Discipline Problems. Unpublished Master's Thesis. Elazığ, Turkey: Institute of Social Sciences, Furat University.

Sözen, S., \& Çabuk, A. (2013). An Analysis of Turkish, German and Austrian Teacher Education System. Uşak University, Journal of Social Sciences, 6(Special Issue), 213-230.

Stemler, S. (2000). An Overview of Content Analysis. Practical Assessment, Research and Evaluation, 7(17), 1-6.

Tavşancıl, E., \& Aslan, A. E. (2001). Content Analysis and Application Samples. İstanbul: Epsilon Publishing.

Tomul, E. (2016). Teacher-Student Communication in Class. In H. Kıran, K. Çelik, \& K. Etkili (eds.), Classroom Management. Ankara: Anı Publishing.

Visser, T. C., Coenders, F. G. M., Terlouw, C., \& Pieters, J. M. (2010). Essential Characteristics for a Professional Development Program for Promoting the Implementation of a Multidisciplinary Science Module. Journal of Science Teacher Education, 21(6), 623-642.

Y1ldırım, A. (1999). Basic Characteristics of Qualitative Research Methods and their Place and Importance in Educational Research. Education and Science, 23(112), 9-17.

Yıldırım, A., \& Şimşek, H. (2018). Qualitative Research Methods in Social Sciences. Ankara: Seçkin Publishing.

Y1lmaz, İ., Yoncalık, O., \& Çimen, Z. (2010). An Evaluation of the Relationship between Communication Ability and Proficiency in Teaching in terms of Student Perceptions (Physical Education and Sport Field). SPORMETER Journal of Physical Education and Sports Sciences, 8(4), 143-150.

Yin, R. K. (2014). Case Study Research: Design and Method. $5^{\text {th }}$ Edition. Thousand Oaks, CA: Sage Publishing.

Zainal, Z. (2007). Case Study as a Research Method. Jurnal Kemanusiaan, 5(1), 1-6. 